\author{
셀레늄강화 버섯폐배지의 급여기간이 비육후기 거세한우의 혈중 \\ 글루타치온 과산화효소활성 및 조직내 셀레늄축적에 미치는 영향 \\ 이성훈* . 박범영** . 여준모* . 김완영* \\ 국립 한국농업전문학교 축산학과*, 농촌진흥청 축산연구소**
}

\title{
Effects of the Supplementation Period of Spent Composts of Selenium-enriched Mushrooms on Plasma Glutathione Peroxidase Activity and Selenium Deposition in Finishing Hanwoo Steers
}

\author{
S. H. Lee*, B. Y. Park**, J. M. Yeo* and W. Y. Kim* \\ Department of Animal Science, Korea National Agricultural College, RDA, Suwon 445-893, Korea*, \\ National Livestock Research Institute, RDA, Suwon 441-706, Korea**
}

\begin{abstract}
This study was conducted to determine effects of different supplementation periods (2, 3 and 4 months) of spent composts of Se-enriched mushrooms (Se-SMC) on plasma glutathione peroxidase (GSH-Px) activity and selenium deposition of finishing Hanwoo steers for the optimal supplementing period determination in order to produce Se-fortified Hanwoo beef. In the present study, 30 Hanwoo steers were allotted to treatments in six groups of five steers per pen. Treatments were separated into control and Se-SMC for each supplementation period. Dietary selenium contents were 0.1 and $0.9 \mathrm{ppm}$ for control and Se-SMC treatments, respectively. At the end of each supplementation period, steers by periods were slaughtered to collect hind leg and liver samples for their selenium analyses. Blood samples were taken to analyze whole blood Se concentration and plasma GSH-Px activity at the last day of each supplementation period.

Dry matter intakes were unaffected by Se-SMC and supplementation periods. In addition, average daily gain was not different between control and Se-SMC treatments and among supplementation periods. There was no difference for total body weight gain between control and Se-SMC treatments within each supplementation period. The supplementation of Se-SMC significantly $(\mathrm{P}<0.001)$ increased whole blood Se concentration, but whole blood selenium concentration was not affected by the supplementation period. Furthermore, plasma GSH-Px activity showed similar trend as shown in the pattern of whole blood Se concentration, but no difference by supplementation periods was observed. Selenium contents in hind legs significantly $(\mathrm{P}<0.05)$ increased with increasing supplementation periods, and also they were significantly $(\mathrm{P}<0.001)$ higher for Se-SMC supplementation groups in comparison to controls. However, there was no difference for selenium contents of hind legs between three and four months supplementation. Selenium contents in livers tended to slightly increase with increasing supplementation periods with no significant difference, but they were significantly $(\mathrm{P}<0.01)$ higher for Se-SMC supplementation groups compared with controls within the same period.

The results indicated that the optimal Se-SMC supplementation period for the selenium deposition in Hanwoo steers might be around two or three months when we considered selenium contents in hind legs and livers. (Key words : Supplementation period, Se-SMC, Glutathione peroxidase, Deposition, Hanwoo steers)
\end{abstract}

Corresponding author : W. Y. Kim, Department of Animal Science, Korea National Agricultural College, RDA, Suwon 445-893, Korea.

Tel : +82-31-229-5032, Fax : +82-31-229-5055. E-mail : wykim@rda.go.kr 


\section{I. 서 론}

사료에 셀레늄을 첨가하여 조직 내 셀레늄함 량을 강화시킨 축산물을 섭취한 인체에서 생리 활성을 나타내는 다양한 종류의 셀레늄함유단 백질(selenoproteins)의 발현이 증가될 수 있을 뿐 만 아니라 셀레늄 부족으로 발생할 수 있는 각종 질병예방에 도움을 줄 수 있다(Finley, 1999). 축 산물내 셀레늄의 축적정도는 축종에 따라 달라 지는데, Wright와 Bell(1966)은 반추동물과 단위 동물간의 비교연구에서 단위동물이 반추동물보 다 2.5배 이상 그 축적효율이 높다고 보고하였 으며, 이는 반추위내 미생물의 작용에 의하여 기인한다고 하였다.

또한, 가축에 화학적 형태가 다른 셀레늄급원 (유기 및 무기)을 급여하였을 때, 유기셀레늄이 무기셀레늄 보다 장관내 흡수 및 축적효율이 높은 것으로 보고되고 있다(Ortman과 Pehrson, 1999; Lawler 등, 2004; Payne 등, 2005). 아울러, 유기셀레늄은 체내 단백질에 비특이적으로 결합 하여 저장되므로(McConnell과 Hoffman, 1972), 각종 축산물(우유, 고기, 계란 등)내 셀레늄 함 량의 증가는 유기셀레늄 급여에 의하여 가능한 것으로 알려지고 있다. 특히 반추동물에서 반 추위내 환원된 환경으로 인하여 대부분의 무기 셀레늄은 반추위내에서 불용성 selenide로 전환 되어 하부장관에서 거의 흡수되지 못하고 분 으로 배설되기에 셀레늄강화 축산물을 생산하 는데 한계가 있는 것으로 보고되고 있다(Butler 와 Peterson, 1961; Hidiroglou 등, 1968).

이에 따라 일반적으로 셀레늄강화 축산물을 생산하기 위하여 유기셀레늄을 사용하고 있고, 대표적인 유기셀레늄제제로 셀레늄강화효모를 들 수 있으며, 이는 주로 체내 이용효율이 높 은 selenomethionine 형태의 셀레늄을 함유하고 있다(Kelly와 Power, 1995). 하지만 셀레늄강화 효모는 가격면에서 축산농가에서 사용하기에는 부담스러운 면이 있다.

한편, 최근 연구에서 가축의 유기셀레늄 공 급기능 뿐만 아니라 부존사료자원의 이용측면 에서 셀레늄강화 버섯폐배지를 셀레늄강화 한 우고기 생산의 사료로 활용한 바 있으며, 비용
이 저렴한 셀레늄강화 버섯폐배지는 셀레늄강 화 버섯을 생산한 후 폐기되는 부산물로서 여 기에는 다량의 섬유질뿐만 아니라 버섯으로 전 이하지 못한 다량의 셀레늄이 존재하여 비육후 기 한우에 일정기간 급여하면 셀레늄강화 한우 고기 생산이 가능한 것으로 보고되고 있다(Lee 등, 2006). 또한 이 등(2005)의 연구보고에 의하 면 버섯폐배지내 셀레늄은 셀레늄강화버섯을 재 배하기 위하여 첨가된 무기셀레늄이 폐배지내 균사에 의하여 유기형태로 전환되어서 주로 유기셀레늄을 함유하는 것으로 조사되었다. 아 울러 Lee 등(2006)의 연구결과에 의하면 셀레 늄강화 버섯폐배지를 비육후기 한우사료에 셀 레늄 함량이 $0.1,0.3,0.6$ 및 $0.9 \mathrm{ppm}$ 으로 함유 되도록 배합하여 90 일간 급여하였을 때, 혈중 셀레늄농도, 조직내 셀레늄 함량이 사료내 셀 레늄 농도가 증가함에 따라 비례적으로 증가하 고, 혈중 항산화효소인 글루타치온 과산화효소 (glutathione peroxidase, GSH-Px) 활성이 증가한 다고 보고하였으며, 이들 변수는 사료내 셀레 늄 농도가 $0.9 \mathrm{ppm}$ 일 때 가장 높은 수치를 나 타내었다.

이에 따라 본 연구에서는 선행연구결과를 토 대로 셀레늄강화 버섯폐배지를 이용하여 셀레 늄강화 한우고기를 생산하기 위하여 사료내 셀 레늄 함량이 $0.9 \mathrm{ppm}$ 함유하도록 버섯폐배지를 배합하여 비육후기 거세한우에 급여할 때 조직 내 셀레늄 포화축적기간을 결정하고자 2, 3, 4 개월간 각각 사육한 후, 혈중 셀레늄농도 및 글루타치온 과산화효소활성 그리고 조직내 셀 레늄 함량을 조사하였다.

\section{ㅍ. 재료 및 방법}

본 연구는 셀레늄강화 한우고기 생산을 위하 여 셀레늄강화 버섯폐배지가 함유된 셀레늄사 료(사료내 셀레늄함량: $0.9 \mathrm{ppm}$ )를 활용하여 급 여사양기간(2개월, 3 개월, 4 개월)을 달리 하였을 때, 비육후기 거세한우의 조직 내 셀레늄 함량 과 혈중 글루타치온 과산화효소 활성에 미치는 영향을 조사하여 최대 포화축적기간을 제시하 고자 실시하였다. 


\section{1. 실험사료}

본 연구에 사용되는 실험사료를 제조하기 위 하여 셀레늄강화 버섯농장과 일반버섯농장에서 각각 버섯폐배지를 수거하여 전남 영암소재 한 우시험농장으로 운반하였다. 버섯폐배지내 셀 레늄 함량은 셀레늄강화 버섯폐배지와 일반 버 섯폐배지에서 각각 2.48 및 $0.08 \mathrm{mg} / \mathrm{kg}$ (원물기 준)으로 조사되었다.

각 버섯폐배지의 셀레늄 함량을 토대로 무셀 레늄첨가사료(대조구) 및 셀레늄강화 버섯폐배 지사료(Se-SMC)를 각각 배합하였고, 이들 실험 사료의 배합비 및 화학적 조성은 Table 1에 나 타내었다. Table 1에서 보는 바와 같이 두 실험 사료는 비육후기 사료에서 요구되는 에너지와 단백질수준에 대하여 건물기준 가소화영양소총 량과 조단백질 함량이 각각 $74 \%$ 와 $11 \%$ 함유되도 록 배합하였고(농림부와 축산기술연구소, 2002), 두 사료의 영양소 함량은 셀레늄을 제외한 거 의 모든 성분이 서로 유사한 분석결과를 나타 내었다. 또한 실험이 실시되는 동안 비육후기 한우에 신선한 사료를 급여하기 위하여 실험사 료는 2주 단위로 제조하였다.

\section{2. 실험설계 및 사양관리}

본 연구는 셀레늄강화 한우고기 생산을 위한 조직내 셀레늄 최대 축적기간을 결정하기 위하 여 급여기간을 비육후기에서 출하시까지 2 개 월, 3 개월, 4 개월로 설정하고 각 기간에 대하여 대조구사료와 셀레늄강화 버섯폐배지사료를 각 각 급여하기 위하여 거세한우를 6군으로 나누 어 각 군당 5 두씩 총 30 두를 공시하였다. 본 연 구에 사용된 거세한우는 체중을 측정한 후, 급 여기간을 고려하여 출하월령이 비슷하도록 배 치하였다. 즉, 2 개월 급여군은 체중이 $621 \mathrm{~kg}$ 이 상, 3개월급여군은 $561 \sim 620 \mathrm{~kg}$, 4개월 급여군 은 $500 \sim 560 \mathrm{~kg}$ 의 소를 각 군에 배치하였다. 사 양 본 시험에 들어가기 1달 전에 시험사료 및 환경에 적응시켰고, 이들의 실험설계는 Table 2 에 나타난 바와 같다.

그리고, 실험사료는 개체별 사료급이기를 통
Table 1. Ingredients and chemical compositions of experimental diets

\begin{tabular}{lcc}
\hline \multirow{2}{*}{ Items } & \multicolumn{2}{c}{ Diets } \\
\cline { 2 - 3 } & Control & Se-SMC \\
\hline \hline Ingredients(\%), as-fed basis & \\
Se-SMC & & 24.60 \\
SMC $^{2)}$ & 24.60 & - \\
Corn, grain & 55.54 & 55.54 \\
Barley, grain & 5.40 & 5.40 \\
Corn gluten meal & 1.89 & 1.89 \\
Tall fescue, straw & 4.74 & 4.74 \\
Barley bran & 1.89 & 1.89 \\
Molasses, sugarcane & 5.85 & 5.85 \\
Vitamin/mineral mix ${ }^{3)}$ & 0.09 & 0.09 \\
\hline Chemical composition, DM basis & \\
Dry matter, \% & 75.85 & 76.23 \\
Crude protein, \% & 11.26 & 11.54 \\
Crude fiber, \% & 12.92 & 12.96 \\
Ether extract, \% & 3.73 & 3.65 \\
Crude ash, \% & 2.80 & 2.70 \\
Nitrogen-free extracts, \% & 69.29 & 69.15 \\
Calcium, \% & 0.49 & 0.43 \\
Phosphorus, \% & 0.18 & 0.19 \\
Selenium, mg/kg & 0.082 & 0.905 \\
TDN ${ }^{4)}$, \% & 74.44 & 74.33 \\
\hline & & \\
\hline
\end{tabular}

1) Se-SMC : spent mushroom composts from Se-enriched mushrooms; ${ }^{2)}$ SMC : spent mushroom composts from normal mushrooms; ${ }^{3)}$ consisted of Ca 15\%, P 6.8\%, Mg 7.0\%, Na 7.8\%, Zn 5,000 mg/kg, Mn 4,000 mg/kg, Cu $500 \mathrm{mg} / \mathrm{kg}$, I $300 \mathrm{mg} / \mathrm{kg}$, Co $20 \mathrm{mg} / \mathrm{kg}$, Se $0 \mathrm{mg} / \mathrm{kg}$, vitamin A 400,000 IU/kg, vitamin $\mathrm{D}_{3} 75,000 \mathrm{IU} / \mathrm{kg}$, and vitamin E $500 \mathrm{mg} / \mathrm{kg} ;{ }^{4)}$ Total digestible nutrients (TDN) value was calculated according to the regression equation described by Wardeh (1981), whose equation is that TDN\% equals $40.2625+(0.1969 \times$ crude protein $\%)+$ $(0.4228 \times$ nitrogen-free extracts\% $)+(1.1905 \times$ ether extract $\%)-(0.1379 \times$ crude fiber\%).

하여 오전(07:00 a.m.)과 오후(17:00 p.m.)로 나누 어 2회 자유 채식시켰고, 물은 자유로이 음수 할 수 있도록 하였으며, 음수내 셀레늄 함량은 $\mathrm{mL}$ 당 $2 \mathrm{ng}$ 이하로 함유하여 분석상에서 감지 
Table 2. The arrangement of Hanwoo steers subjected to this trial

\begin{tabular}{|c|c|c|c|c|}
\hline \multirow{2}{*}{ Diets } & \multicolumn{3}{|c|}{ Supplementation period } & \multirow{2}{*}{ Total } \\
\hline & 2 months & 3 months & 4 months & \\
\hline Control & $5^{2)}$ & 5 & 5 & 15 \\
\hline Se-SMC ${ }^{1)}$ & 5 & 5 & 5 & 15 \\
\hline Total & 10 & 10 & 10 & 30 \\
\hline
\end{tabular}

1) Spent composts of Se-enriched mushrooms; ${ }^{2)}$ the number of finishing Hanwoo steers within each group.

되지 않는 수준이었다. 사료섭취량은 1일 2회 급여량과 다음날 아침 사료급여 전 잔여사료를 수거하여 그 차이에 의해 계산하였다.

체중은 시험소의 스트레스최소화를 위하여 시험 개시체중과 종료체중만을 측정하였고, 증 체량은 시험개시체중과 종료체중의 차이로 구하 였다. 각 사료급여기간이 종료되는 시험소들은 근육과 간내 존재하는 셀레늄 함량을 조사하기 위하여 전남 나주농협공판장으로 운반하여 도 축하였다. 그리고 실험을 실시하는 동안 셀레 늄강화 버섯폐배지의 급여기간에 따른 거세한 우의 혈중 셀레늄농도 및 혈장내 항산화효소인 글루타치온 과산화효소(GSH-Px) 활성을 측정하 기 위하여 도축 시에 채혈을 실시하였다.

\section{3. 혈액 및 시료채취}

혈액 샘플의 채취는 혈중 셀레늄 분석과 혈 장내 GSH-Px 활성분석을 위해 경정맥을 통하 여 $10 \mathrm{~mL}$ 항혈액응고제가 처리된 진공시험관 (Becton-Dickinson社, 미국)을 이용하여 수집한 후, 파쇄얼음이 보관된 아이스박스에 담았다. 그리고 채혈작업이 종료되면 효소 분석용 혈액 은 혈구분리를 위해 아이스박스에서 혈액을 꺼 내어 온도가 $4^{\circ} \mathrm{C}$ 로 유지된 원심분리기에서 3,000 $\times \mathrm{g} 15$ 분간 원심분리하였으며, 분리된 혈장은 실 험실로 운반하여 분석 시까지 $-75^{\circ} \mathrm{C}$ 냉동고에 보관하였다.

한편, 각 급여기간(2개월, 3개월, 4개월)이 끝 나면 대조구사료와 Se-SMC 급여구 각각 5두씩,
즉, 총 10 두씩을 개체별로 체중을 측정한 후, 전남 나주농협공판장에서 도축하였고, 후지 및 간에 전이된 셀레늄 분석을 위해 간은 도축 후 바로 적출하였으며, 후지는 등급판정이 끝난 후 부분육 분할시 시료를 채취 - 진공 포장하여 실험실로 운반하였다.

\section{4. 시험사료, 혈액 및 조직내 셀레늄 분석}

실험사료의 일반성분은 AOAC(1995) 방법에 따라 분석하였고, 실험사료 내 셀레늄 분석은 동결건조기(OPERON, 한국)에서 3일간 건조하 여 수분을 완전히 제거하여 분쇄기로 $1 \mathrm{~mm}$ 이 하의 입자크기로 분쇄한 후 이 등(2005)의 방법 에 따라 산소플라스크연소법으로 연소시킨 후, $\mathrm{AOAC}(1995)$ 방법으로 분석하였고, 혈액과 후 지 및 간은 동결건조기에서 7일간 건조하여 사 료내 셀레늄 분석과 동일한 방법으로 분석하였 다.

\section{5. 혈장 글루타치온 과산화효소(GSH-Px) 활 성 분석}

혈장 내 GSH-Px 활성은 Lawrence와 Burk(1976) 의 방법에 따라 spectrophotometer(Shimadzu, Japan) 를 이용하여 $340 \mathrm{~nm}$ 에서 3 분간 10 초 간격으로 읽어서 나타나는 slope을 이용하여 활성을 측 정하였고, 분석에 이용된 모든 시약은 Sigma 제품을 사용하였다. GSH-Px의 1단위(1unit)는 혈장 $1 \mathrm{~mL}$ 기준으로 1 분 동안 산화된 $1 \mathrm{nmol}$ 의 $\mathrm{NADPH}$ 량으로 나타내었다.

\section{6. 통계분석}

본 실험에서 얻어진 사료섭취량 및 증체량 그리고 조직과 혈액내 셀레늄 함량에 대한 자 료는 사료내 셀레늄과 급여기간이 이들 변수들 에 영향을 미치는지 조사하기위해 각 실험사 료 처리구의 소 두수(각 5두) 반복을 하여 SAS package program(2000, release. 8.1 ver.)의 two way ANOVA procedure를 이용하여 셀레늄 강화 
버섯폐배지(Se-SMC) 효과, 급여기간 효과 및 이 들의 상호효과에 대하여 $3 \times 2$ 요인실험(factorial design arrangement)으로 통계 처리하였다. 각 처리구간 평균값의 유의성 검정은 $\mathrm{P}$ 값 $5 \%$ 수준에서 Duncan 다중검정으로 하였다(Steel과 Torrie, 1980).

\section{III. 결과 및 고찰}

셀레늄강화 버섯폐배지(Se-SMC)의 급여기간 이 사료건물섭취량에 미치는 영향은 Table 3에 나타내었다. 표에서 나타낸 바와 같이 비육후 기 한우의 건물섭취량은 Se-SMC 급여기간 및 Se-SMC 급여로 인한 사료내 셀레늄수준 증가 에 의하여 처리구 간에 유의한 차이가 나타나 지 않았고, 전체 처리구의 1 일 평균 섭취량은 약 $9.7 \mathrm{~kg}$ 을 나타내었으며, 본 결과로부터 셀레 늄이 사료섭취의 제한요인으로 나타나지 않음 을 알 수 있었다.

Lawler 등(2004)은 다양한 셀레늄 급원을 비 육우에 급여하였을 때, 처리구간에 차이가 나타 나지 않는 것으로 보고하였고, Gunter 등(2003) 도 유-무기셀레늄을 임신우에 급여한 결과 건 초의 섭취량이 처리구간에 차이가 나타나지 않 았다고 보고하였다. 아울러 Lee 등(2006)의 연 구에서도 셀레늄수준별(0.1, 0.3, 0.6, $0.9 \mathrm{ppm} \mathrm{Se})$
로 셀레늄강화 버섯폐배지를 급여한 결과 처리 구간에 차이가 나타나지 않는 것으로 보고되어 본 연구에서 나타난 결과는 이전 연구자의 결 과와 일치하였다.

본 연구에서 Se-SMC의 급여기간시험으로 인 한 실험기간동안 중독증상은 나타나지 않았다. 소에 대한 셀레늄 독성을 나타내는 사료내 수 준이 아직 광범위하게 알려져 있지 않지만, 돼 지의 경우 Kim과 Mahan(2001)은 사료내 셀레 늄이 $5 \mathrm{ppm}$ 이상으로 증가함에 따라 일당증체 량, 사료섭취량 및 최종체중이 감소한다고 보 고하여 중독성을 시사한 바 있고, 이에 반하여 반추동물에서 Cristaldi 등(2005)은 사료내 셀레 늄수준 $10 \mathrm{ppm}$ 까지는 중독증상이 나타나지 않 는다고 보고하여 반추동물이 단위동물에 비하 여 사료내 높은 수준의 셀레늄에 대하여 덜 민 감한 것으로 판단된다.

본 연구의 실험군은 비육체중에 따라 2 개월 급여군(평균 개시체중 $677 \mathrm{~kg}$ ), 3개월 급여군(평 균 개시체중 $610 \mathrm{~kg}$ ), 4개월 급여군(평균 개시체 중 $524 \mathrm{~kg}$ )으로 나누어 사료를 급여하였고, 체 중에 따른 섭취량의 차이 또한 나타나지 않았 다. 본 결과는 안 등(2002)의 연구에서 나타난 체중별 거세한우에 대한 섭취수준과 유사하였 다.

셀레늄강화 버섯폐배지의 급여기간이 증체량

Table 3. Effects of supplementation periods of spent composts of Se-enriched mushrooms (Se-SMC) on feed intake of finishing Hanwoo steers

\begin{tabular}{|c|c|c|c|c|c|c|c|c|c|c|}
\hline \multirow{3}{*}{$\begin{array}{c}\text { Period } \\
\text { (month) }\end{array}$} & \multicolumn{6}{|c|}{ Supplementation period } & \multirow{3}{*}{$\mathrm{SEM}^{1)}$} & \multicolumn{3}{|c|}{ P-value } \\
\hline & \multicolumn{2}{|c|}{2 months } & \multicolumn{2}{|c|}{3 months } & \multicolumn{2}{|c|}{4 months } & & \multirow[b]{2}{*}{ Period $^{2)}$} & \multirow[b]{2}{*}{ Se-SMC ${ }^{3)}$} & \multirow{2}{*}{$\begin{array}{l}\text { Period } \times \\
\text { Se-SMC }\end{array}$} \\
\hline & Control & Se-SMC & Control & Se-SMC & Control & Se-SMC & & & & \\
\hline & ......... & ... Dry $\mathrm{m}$ & atter intal & re $(\mathrm{kg} / \mathrm{hea}$ & day) ... & .......... & & & & \\
\hline 1 & 9.85 & 9.76 & 9.52 & 9.49 & 9.29 & 9.35 & 1.27 & 0.9596 & 0.9942 & 0.9732 \\
\hline 2 & 9.88 & 9.82 & 9.63 & 9.53 & 9.37 & 9.33 & 0.96 & 0.9732 & 0.9635 & 0.9532 \\
\hline 3 & - & - & 9.84 & 9.92 & 9.58 & 9.90 & 0.77 & 0.9648 & 0.9654 & 0.9873 \\
\hline 4 & - & - & - & - & 9.72 & 9.55 & 0.52 & - & 0.9942 & - \\
\hline Overall & 9.87 & 9.79 & 9.66 & 9.65 & 9.49 & 9.53 & 0.38 & 0.9724 & 0.9847 & 0.9573 \\
\hline
\end{tabular}

1) Standard error of the mean; ${ }^{2)}$ supplementation period effect; ${ }^{3)}$ Se-SMC effect; ${ }^{4)}$ interaction between supplementation period and Se-SMC. 
에 미치는 영향은 Table 4에 나타난 바와 같다. 사양시험 개시체중과 종료체중은 급여기간에 의하여 유의한 차이를 나타내었고 $(\mathrm{P}<0.05)$, 급여 기간이 증가함에 따라 유의하게 낮았다 $(\mathrm{P}<0.05)$. 이는 사양시험 시작시 체중의 차이에 의한 배 치로 인한 것으로 생각된다.

하지만, 총 증체량은 급여기간에 의하여 유 의한 차이를 나타내었는데, 즉 급여기간이 증 가함에 따라 유의하게 증가하였다 $(\mathrm{P}<0.001)$. 이 는 사양기간의 증가로 인한 증체허용시간이 길 어져서 나타난 결과로 사료된다. 하지만 동일 한 급여기간내에서 Se-SMC에 의한 증체량의
차이는 나타나지 않았다. 아울러 일당증체량 또한 급여기간 및 Se-SMC에 의하여 유의한 차 이가 나타나지 않았다. Awadeh 등(1998)과 Rock 등(2001)의 연구에서 비육암소 및 임신면양에 유-무기셀레늄을 첨가하여 급여한 결과 증체 량에는 영향을 미치지 않는다고 보고하여 본 연구에서도 이와 일치된 결과를 나타내었다.

셀레늄강화 버섯폐배지의 급여기간이 혈중 셀 레늄 농도와 글루타치온 과산화효소활성(GSH-Px) 에 미치는 영향은 Table 5에 나타내었다. 표에 서 나타난 바와 같이 사료내 셀레늄수준 즉, Se-SMC 급여는 한우의 혈중셀레늄농도를 유의

Table 4. Effects of supplementation periods of spent composts of Se-enriched mushrooms (Se-SMC) on body weight gain of finishing Hanwoo steers

\begin{tabular}{|c|c|c|c|c|c|c|c|c|c|c|}
\hline \multirow{3}{*}{ Items } & \multicolumn{6}{|c|}{ Supplementation period } & \multirow{3}{*}{$\mathrm{SEM}^{1)}$} & \multicolumn{3}{|c|}{ P-value } \\
\hline & \multicolumn{2}{|c|}{2 months } & \multicolumn{2}{|c|}{3 months } & \multicolumn{2}{|c|}{4 months } & & \multirow{2}{*}{ Period $^{2)}$} & \multirow{2}{*}{ Se-SMC ${ }^{3)}$} & \multirow{2}{*}{$\begin{array}{c}\text { Period } \times \\
\text { Se-SMC }^{4}\end{array}$} \\
\hline & Control & Se-SMC & Control & Se-SMC & Control & Se-SMC & & & & \\
\hline & & ….... & Perfor & nance $\cdot \cdot$ & (.......... & ......... & & & & \\
\hline Initial BW (kg) & $676.5^{\mathrm{a}}$ & $677.5^{\mathrm{a}}$ & $610.0^{\mathrm{b}}$ & $609.0^{\mathrm{b}}$ & $524.8^{\mathrm{c}}$ & $523.0^{c}$ & 26.52 & $<0.0001$ & 0.9576 & 0.9943 \\
\hline Final BW (kg) & $721.8^{\mathrm{a}}$ & $719.8^{\mathrm{a}}$ & $680.8^{\mathrm{a}}$ & $683.3^{\mathrm{a}}$ & $633.0^{\mathrm{b}}$ & $618.0^{b}$ & 26.17 & $<0.0001$ & 0.6564 & 0.7882 \\
\hline $\mathrm{ADG}^{5)}(\mathrm{g})$ & 757.5 & 707.5 & 787.5 & 825.0 & 902.5 & 790.0 & 107.96 & 0.1305 & 0.3570 & 0.3966 \\
\hline Total gain $(\mathrm{kg})$ & $45.3^{c}$ & $42.3^{c}$ & $70.8^{\mathrm{b}}$ & $74.3^{\mathrm{b}}$ & $108.3^{\mathrm{a}}$ & $95.0^{\mathrm{a}}$ & 11.08 & $<0.0001$ & 0.3601 & 0.3356 \\
\hline
\end{tabular}

1) Standard error of the mean; ${ }^{2)}$ supplementation period effect; ${ }^{3)}$ Se-SMC effect; ${ }^{4)}$ interaction between supplementation period and Se-SMC; ${ }^{5)}$ average daily gain;

a,b,c different superscripts within the same row are significantly different $(\mathrm{P}<0.05)$.

Table 5. Effects of supplementation periods of spent composts of Se-enriched mushrooms (Se-SMC) on whole blood selenium concentrations and plasma glutathione peroxidase activity in finishing Hanwoo steers

\begin{tabular}{|c|c|c|c|c|c|c|c|c|c|c|}
\hline \multirow{3}{*}{ Items } & \multicolumn{6}{|c|}{ Supplementation period } & \multirow{3}{*}{ SEM $^{1)}$} & \multicolumn{3}{|c|}{ P-value } \\
\hline & \multicolumn{2}{|c|}{2 months } & \multicolumn{2}{|c|}{3 months } & \multicolumn{2}{|c|}{4 months } & & \multirow{2}{*}{ Period $^{2)}$} & \multirow[b]{2}{*}{ Se-SMC ${ }^{3)}$} & \multirow{2}{*}{$\begin{array}{l}\text { Period } \times \\
\text { Se-SMC }^{4)} \\
\end{array}$} \\
\hline & Control & Se-SMC & Control & Se-SMC & Control & Se-SMC & & & & \\
\hline & (n......... & ..... Selen & ium conc & entration & $(\mathrm{ng} / \mathrm{mL})$ & $\ldots \ldots \ldots \ldots$ & & & & \\
\hline \multirow[t]{2}{*}{ Blood } & $104.21^{\mathrm{b}}$ & $255.62^{\mathrm{a}}$ & $87.67^{\mathrm{b}}$ & $250.49^{\mathrm{a}}$ & $91.27^{\mathrm{b}}$ & $265.33^{a}$ & 9.78 & 0.1527 & $<0.0001$ & 0.1627 \\
\hline & .......... & ....... G & H-Px act & ivity ${ }^{5)}$ (u & it) $\ldots \ldots$. & & & & & \\
\hline Plasma & $12.858^{\mathrm{b}}$ & $41.948^{\mathrm{a}}$ & $12.418^{\mathrm{b}}$ & $35.711^{\mathrm{a}}$ & $13.911^{\mathrm{b}}$ & $46.007^{\mathrm{a}}$ & 5.42 & 0.0794 & $<0.0001$ & 0.1122 \\
\hline
\end{tabular}

${ }^{1)}$ Standard error of the mean; ${ }^{2)}$ supplementation period effect; ${ }^{3)}$ Se-SMC effect; ${ }^{4}$ interaction between supplementation period and Se-SMC; ${ }^{5}$ one unit of activity equals $1 \mathrm{nmol}$ NADPH oxidized per minute/per milliliter of blood plasma; ${ }^{\mathrm{a}, \mathrm{b}}$ different superscripts within the same row are significantly different $(\mathrm{P}<0.05)$. 
하게 증가시켰으나 $(\mathrm{P}<0.001)$, 급여기간에 따른 효과는 나타나지 않았다. 그리고 셀레늄 무처 리구인 대조구는 급여기간이 증가함에 따라 유 의한 변화가 나타나지 않았고, 이는 Lee 등 (2006)이 보고한 연구결과와 유사하였다. 일반 적으로 셀레늄의 장관내 흡수는 셀레늄의 화학 적 형태에 따라 달라지고, 유기셀레늄의 급여에 의하여 혈중 셀레늄농도를 증가시키고, 이와 더 불어 혈중 셀레늄 구성효소인 글루타치온 과산 화효소 활성을 증가시키는 것으로 보고되고 있 다(Jacobsson, 1966; van Ryssen 등, 1989; Gunter 등, 2003). 이에 따라 본 연구에서 사용된 셀레 늄강화 버섯폐배지의 급여를 통한 급격한 혈중 셀레늄농도 증가로 인하여 장관내 흡수가 우수 한 것으로 판단되고, 이는 이 등(2005)이 보고 한 셀레늄강화 버섯폐배지내 셀레늄이 유기형 태로 존재한다는 것을 뒷받침해 주었다.

그리고 Table 5에서 보는 바와 같이 혈중 셀 레늄농도는 Se-SMC 급여기간과는 관계가 없는 것으로 나타났지만, 대조구에 비하여 Se-SMC 구에서 증가된 혈중 셀레늄농도는 급여기간의 증가에 따른 조직으로 이행하는 혈액내 셀레늄 양이 증가하여 체내 저장셀레늄이 증가할 수 있으므로 결국엔 근육내에서 증가된 수준으로 셀레늄이 존재할 가능성이 높다고 할 수 있다.

한편, 본 연구의 GSH-Px 활성은 혈액 내 셀 레늄농도와 유사한 경향을 나타내었고, 폐배지 내 셀레늄은 거세한우의 GSH-Px 활성을 유의 하게 증가시켰다 $(\mathrm{P}<0.001)$. 그리고, 급여기간에 따른 GSH-Px 활성의 차이는 혈중 셀레늄농도 와 마찬가지로 발견되지 않았다. 일반적으로 혈중 GSH-Px 활성은 혈중 셀레늄 농도와 정 $(+)$ 의 상관관계를 가지고(Hintze 등, 2002; 이 등, 2004), 본 연구에서도 Se-SMC의 급여로 인한 혈 중 셀레늄 농도의 증가와 함께 GSH-Px 활성이 증가하였다. 이상의 결과에서 급여기간에 따른 GSH-Px 활성은 Se-SMC 급여에 의한 효과만 뚜 렷하게 나타났고, 급여기간과 GSH-Px 활성간의 상관도가 나타나지 않는 것으로 나타났으며, 혈 중 GSH-Px 활성은 사료내 셀레늄의 급여를 통 한 혈중 셀레늄농도 증가에 의하여 발현되는 것으로 판단되었다.
셀레늄강화 버섯폐배지의 급여기간이 근육 및 간내 셀레늄 침착에 미치는 영향은 Table 6 에 나타내었다. 후지내 셀레늄 함량은 급여기 간 $(\mathrm{P}<0.05)$ 과 $\mathrm{Se}-\mathrm{SMC}$ 급여 $(\mathrm{P}<0.001)$ 에 의하여 유의하게 증가하였다. 하지만, Se-SMC의 3개월 급여군과 4 개월 급여군간에는 유의한 차이가 나타나지 않았으며, 이는 근육내 셀레늄 축적 이 급여기간 3 내지 4 개월 사이에 더 이상 축적 되지 않고, 일정수준으로 유지되는 것을 알 수 있다. 간내 셀레늄 함량은 Se-SMC의 급여기간 이 증가함에 따라 다소 증가하는 경향을 나타 내었으나 유의한 효과는 나타나지 않았다. 하 지만, 동일 급여기간내 Se-SMC 처리구의 간내 셀레늄 함량은 대조구에 비하여 유의하게 높 았다 $(\mathrm{P}<0.01)$. 그리고 대조구의 후지 및 간내 셀레늄 함량은 급여기간이 증가하여도 변화가 없는 것으로 나타났다.

국내외적으로 셀레늄강화 쇠고기를 생산하기 위하여 셀레늄 사료급여기간에 따른 조직내 셀 레늄 함량에 관한 연구보고는 충분히 알려져 있 지 않다. 하지만, 일반적으로 반추동물에서 조 직내 셀레늄 함량은 혈중 셀레늄 농도와 밀접 한 상관관계 $(\mathrm{r}=0.66)$ 를 가지는 것으로 알려져 있고(Hintze 등, 2001), 본 연구의 혈중 셀레늄 농도결과를 비추어 보면, Se-SMC의 급여에 의 한 혈중 셀레늄 농도가 증가하였고, 이에 따라 후지내 셀레늄 함량이 증가한 것으로 판단되 고, 급여기간에 따른 효과는 혈중 순환되는 셀 레늄이 급여기간만큼 조직으로 운반되어 저장 됨에 따라 셀레늄 양이 증가되어 나타난 결과 인 것으로 사료된다.

아울러 Table 6에 나타난 바와 같이 간내 셀 레늄 함량은 근육내 셀레늄에 비하여 전반적으 로 높은 값을 나타내었다. 일반적으로 간은 셀 레늄대사의 높은 활성을 나타내는 기관으로 높 은 셀레늄 농도를 함유하는 것으로 알려져 있 고, 체내 기관별로 셀레늄 함량은 신장이 가장 높고, 다음이 간, 췌장, 심장 및 근육순으로 낮아 지는 것으로 알려져 있다(Combs와 Combs, 1986).

본 결과에서 근육내 셀레늄 함량을 고려하여 셀레늄강화 버섯폐배지를 2개월간 급여하여도 대조구보다 유의하게 높은 셀레늄 함량을 가져 
Table 6. Effects of supplementation periods of spent composts of Se-enriched mushrooms (Se-SMC) on selenium deposition in Hanwoo steers

\begin{tabular}{|c|c|c|c|c|c|c|c|c|c|c|}
\hline \multirow{3}{*}{ Items } & \multicolumn{6}{|c|}{ Supplementation period } & \multirow{3}{*}{$\mathrm{SEM}^{1)}$} & \multicolumn{3}{|c|}{ P-value } \\
\hline & \multirow{2}{*}{\multicolumn{2}{|c|}{$\begin{array}{c}2 \text { months } \\
\text { Control Se-SMC } \\
\end{array}$}} & \multirow{2}{*}{\multicolumn{2}{|c|}{$\begin{array}{c}3 \text { months } \\
\text { Control Se-SMC } \\
\end{array}$}} & \multicolumn{2}{|c|}{4 months } & & \multirow{2}{*}{ Period $^{2)}$} & \multirow{2}{*}{ Se-SMC ${ }^{3)}$} & \multirow{2}{*}{$\begin{array}{l}\text { Period } \times \\
\text { Se-SMC }^{4} \\
\end{array}$} \\
\hline & & & & & Control & Se-SMC & & & & \\
\hline & $\ldots \ldots \ldots$ & ...... Tiss & Se, $\mu \mathrm{g} / \mathrm{g}$ & of dry we & ght $\ldots . .$. . & $\ldots \ldots \ldots$, & & & & \\
\hline Hind leg & $0.453^{c}$ & $0.587^{\mathrm{b}}$ & $0.471^{\mathrm{c}}$ & $0.672^{\mathrm{ab}}$ & $0.428^{c}$ & $0.733^{\mathrm{a}}$ & 0.0452 & 0.0464 & 0.0002 & 0.0933 \\
\hline Liver & $1.069^{\mathrm{b}}$ & $2.105^{\mathrm{a}}$ & $1.103^{\mathrm{b}}$ & $2.330^{\mathrm{a}}$ & $1.125^{\mathrm{b}}$ & $2.430^{\mathrm{a}}$ & 0.2211 & 0.5012 & $<0.0001$ & 0.6932 \\
\hline
\end{tabular}

1) Standard error of the mean; ${ }^{2)}$ supplementation period effect; ${ }^{3)}$ Se-SMC effect; ${ }^{4)}$ interaction between supplementation period and Se-SMC; ${ }^{a, b, c}$ different superscripts within the same row are significantly different $(\mathrm{P}<0.05)$.

셀레늄강화 한우고기 생산이 가능하였다. 반면, 4 개월간의 Se-SMC 급여는 3개월간 급여와 유 의한 차이를 나타내지 않아 4개월간의 Se-SMC 급여는 조직내 셀레늄축적면에서 비생산적인 것으로 판단되었다. 따라서 근육내 셀레늄 축 적을 위한 적정 Se-SMC 급여기간은 약 2 내지 3 개월이 적절할 것으로 사료된다.

\section{IV. 요 약}

본 연구는 셀레늄강화 한우고기 생산을 위하 여 셀레늄강화 버섯폐배지(Se-SMC)가 함유된 셀 레늄사료(사료내 셀레늄함량: $0.9 \mathrm{ppm}$ )를 활용하 여 급여사양기간(2개월, 3 개월, 4 개월)을 달리 하 였을 때, 비육후기 거세한우의 조직 내 셀레늄 함량과 혈중 글루타치온 과산화효소(GSH-Px) 활성에 미치는 영향을 조사하여 최대 포화축적 기간을 제시하고자 실시하였다. 본 연구에 사 용된 비육후기 거세한우는 30 두로 각 급여기 간(2개월: 평균 체중 $677 \mathrm{~kg}, 3$ 개월: 평균 체중 $610 \mathrm{~kg}$ 및 4개월: 평균 체중 $524 \mathrm{~kg}$ )에 대한 대 조구 및 Se-SMC 급여구로 나누어 처리구당 5 두씩 배치하여 총 6처리구로 구분하여 실시하였 다. 대조구와 Se-SMC 급여구에 사용된 실험사료 는 0.1 과 $0.9 \mathrm{ppm}$ 의 셀레늄을 각각 함유하였다. 각 급여기간이 종료되면 도축하여 후지와 간을 채취하였으며 이를 셀레늄 함량분석에 이용하였 다. 그리고 혈중 셀레늄 농도 및 글루타치온 과산 화효소활성을 분석하기 위하여 도축 시에 채혈 을 실시하였다.
건물섭취량은 Se-SMC 급여 및 급여기간에 의하여 유의한 차이가 나타나지 않았다. 또한 일당증체량은 대조구 및 Se-SMC 급여구간 그 리고 급여기간 간에 유의한 차이가 나타나지 않았을 뿐만 아니라 총증체량 또한 각 급여기 간내 대조구와 Se-SMC 급여구 간에 유의한 차 이가 나타나지 않았다. Se-SMC 급여는 혈중 셀 레늄농도를 유의하게 증가시켰으나 $(\mathrm{P}<0.001)$, 급 여기간에 따른 혈중셀레늄 농도에는 유의한 영 향을 미치지 않았다. 아울러 혈중 GSH-Px 활성 은 혈중 셀레늄농도에서 나타난 양상과 유사한 경향을 나타내었고, 급여기간에 의한 효과는 나타나지 않았다. 후지내 셀레늄 함량은 급여 기간 $(\mathrm{P}<0.05)$ 이 증가함에 따라, 그리고 Se-SMC 급여 $(\mathrm{P}<0.001)$ 에 의하여 유의하게 증가하였다. 하지만, Se-SMC의 3개월 급여군과 4개월 급여 군 간에는 유의한 차이가 나타나지 않았다. 간 내 셀레늄 함량은 Se-SMC의 급여기간이 증가 함에 따라 다소 증가하는 경향을 나타내었으나 유의한 효과는 나타나지 않았다. 하지만, 동일 한 급여기간 내 Se-SMC는 대조구에 비하여 유 의하게 높았다 $(\mathrm{P}<0.01)$.

이상의 결과로부터 근육내 셀레늄 축적을 위 한 적정 Se-SMC 급여기간은 후지와 간내 셀레 늄 함량을 고려할 때 약 2 내지 3 개월의 급여 가 충분할 것으로 사료된다.

$$
\mathrm{V} \text {. 사 사 }
$$

본 연구는 농림부 농림기술개발사업과제 
(202115-03-SB010) 수행결과의 일부로 연구비 지 원에 감사드립니다.

\section{VI. 인 용 문 헌}

1. AOAC. 1995. Official Methods of Analysis. 16th ed. Association of Official Analytical Chemists, Washington, DC.

2. Awadeh, F. T., Abdelrahman, M. M., Kincaid, R. L. and Finley, J. W. 1998. Effect of selenium supplements on the distribution of selenium among serum proteins in cattle. J. Dairy Sci. 81:10891094.

3. Butler, G. W. and Peterson, P. J. 1961. Aspects of the fecal excretion of selenium by sheep. NZ J. Agric. Res. 4:484-491.

4. Combs Jr., G. F. and Combs, S. B. 1986. The role of selenium in nutrition. Academic Press. Inc., New York, NY.

5. Cristaldi, L. A., McDowell, L. R., Buergelt, C. D., Davis, P. A., Wilkinson, N. S. and Martin, F. G. 2005. Tolerance of inorganic selenium in wether sheep. Small Rumin. Res. 56:205-213.

6. Finley, J. W. 1999. Does selenium accumulation in meat confer a health benefit to the consumer? Proc. Am. Soc. Anim. Sci. Available: http://www.asas. org/JAS/symposia/proceedings/0911.pdf. Accessed Nov. 24, 2005.

7. Gunter, S. A., Beck, P. A. and Phillips, J. M. 2003. Effects of supplementary selenium source on the performance and blood measurements in beef cows and their calves. J. Anim. Sci. 81:856864.

8. Hidiroglou, M. D., Heanley, P. and Jenkins, K. J. 1968. Metabolism of inorganic selenium in rumen bacteria. Can. J. Physiol. Pharm. 46:229-232.

9. Hintze, K. J., Lardy, G. P., Marchello, M. J. and Finley, J. W. 2001. Areas with high concentrations of selenium in the soil and forage produce beef with enhanced concentrations of selenium. J. Agric. Food Chem. 49:1062-1067.

10. Hintze, K. J., Lardy, G. P., Marchello, M. J. and
Finley, J. W. 2002. Selenium accumulation in beef: Effect of dietary selenium and geographical area of animal origin. J. Agric. Food Chem. 50:39383942.

11. Jacobsson, S. O. 1966. Uptake of ${ }^{75} \mathrm{Se}$ in tissues of sheep after administration of a single dose of ${ }^{75}$ Se-sodium selenite, ${ }^{75}$ Se-selenomethionine or ${ }^{75}$ Se-selenocystine. Acta Vet. Scand. 7:303-320.

12. Kelly, M. P. and Power, R. F. 1995. Fractionation and identification of the major selenium containing compounds in selenized yeast. J. Dairy Sci. 78 (Supp. 1):237 (abstract).

13. Kim, Y. Y. and Mahan, D. C. 2001. Comparative effects of high dietary levels of organic and inorganic selenium on selenium toxicity of growingfinishing pigs. J. Anim. Sci. 79:942-948.

14. Lawler, T. L., Taylor, J. B., Finley, J. W. and Caton, J. S. 2004. Effect of supranutritional and organically bound selenium on performance, carcass characteristics, and selenium distribution in finishing beef steers. J. Anim. Sci. 82:1488-1493.

15. Lawrence, R. A. and Burk, R. F. 1976. Glutathione peroxidase activity in selenium-deficient rat liver. Biochem. Biophys. Res. Commun. 71:952-958.

16. Lee, S. H., Park, B. Y., Lee, S. S., Choi, N. J., Lee, J. H., Yeo, J. M., Ha, J. K., Maeng, W. J. and Kim, W. Y. 2006. Effects of spent composts of selenium-enriched mushroom and sodium selenite on plasma glutathione peroxidase activity and selenium deposition in finishing Hanwoo steers. Asian-Aust. J. Anim. Sci. 19(7):984-991.

17. McConnell, K. P. and Hoffman, J. L. 1972. Methionine-selenomethionine parallels in rat liver polypeptide chain synthesis. Fed. Proc. 31:691 (abstract).

18. Ortman, K. and Pehrson, B. 1999. Effect of selenate as a feed supplement to dairy cows in comparison to selenite and selenium yeast. J. Anim. Sci. 77:3365-3370.

19. Payne, R. L., Lavergne, T. K. and Southern, L. L. 2005. Effect of inorganic versus organic selenium on hen production and egg selenium 
concentration. Poult. Sci. 84:232-237.

20. Rock, M. J., Kincaid, R. L. and Carstens, G. E. 2001. Effects of prenatal source and level of dietary selenium on passive immunity and thermometabolism of newborn lambs. Small Rumin. Res. 40:129-138.

21. SAS Institute Inc. 2000. SAS/STAT User's Guide (Release 8.1 ed.). Statistics, SAS Inst, Inc., Cary, NC.

22. Steel, R. G. D. and Torrie, J. H. 1980. Principles and Procedures of Statistics: A Biometrical Approach (2nd Ed.). McGraw-Hill Book Co., New York.

23. Van Ryssen, J. B. J., Deagen, J. T., Beilstein, M. A. and Whanger, P. D. 1989. Comparative metabolism of organic and inorganic selenium by sheep. J. Agric. Food Chem. 37:1358-1363.

24. Wardeh, M. F. 1981. Models for estimating energy and protein utilization for feeds. Ph.D. Dissertation; Utah State Univ., Logan.
25. Wright, P. L. and Bell, M. C. 1966. Comparative metabolism of selenium and tellurium in sheep and swine. Am. J. Physiol. 211:6-10.

26. 농림부, 축산기술연구소. 2002. 한국사양표준 한 우.

27. 안병홍, 송성철, 류재숙, 2002. 조사료와 농후사 료의 급여비율이 한우 거세우의 성장 및 도체특 성에 미치는 영향. 한국동물자원과학회지 44(6): 747-756.

28. 이성훈, 곽완섭, 김완영. 2005. 셀레늄강화 팽이 버섯과 폐배지의 셀레늄 형태 및 팽이버섯내 셀 레늄 축적대사에 관한 연구. 한국동물자원과학회 지. 47(2):305-316.

29. 이성훈, 박범영, 김완영. 2004. 셀레늄급원으로 셀레늄강화버섯 폐배지의 급여가 거세한우의 도 체특성, 혈중 GSH-Px 활성 및 조직내 셀레늄 축 적에 미치는 영향. 한국동물자원과학회지. 46(5): 799-810.

(접수일자 : 2006. 10. 16. / 채택일자 : 2006. 12. 12.) 